\title{
PROCESSO DE CRIAÇÃO EM WEBSITES: UM ESTUDO DE CASO DO SITE IESAM
}

\author{
Douglas Junio Fernandes Assumpção ${ }^{1}$ \\ Greicy Marianne Lopes G. C. Villegas ${ }^{2}$
}

\begin{abstract}
Resumo
Um site é o produto final de uma rede simbiótica de profissionais envolvidos no processo de criação. Deste modo, a pesquisa parte da análise do processo de criação, sob a visão da crítica genética, tendo como objeto de estudo o site do Instituto de Estudos Superiores da Amazônia (IESAM), no ano de 2012. Assim, iniciamos o trabalho pelo levantamento dos documentos do processo de criação do site selecionado para estudo. Entre esses documentos existem briefing, esboços de planejamentos, desenvolvimento de sites, arquivos digitais, entre outros. Com este estudo, constatou-se que o processo criativo do web site em questão não ocorreu de forma linear, pois permitiu o uso de mecanismos que proporcionam a legibilidade dos conteúdos a serem transmitidos por meio da composição da mensagem visual.
\end{abstract}

Palavras-chave: Crítica genética, processo de criação, web.

\begin{abstract}
A website is the result of a symbiotic network of professionals involved in the creation process. Thus, the research begins with the analysis of creation process, by using genetic criticism. Its aim is to study the website of the Instituto de Estudos Superiores da Amazônia (IESAM) in the year 2012. Thus, we begin this research by observing documents of the creation process of the website. Among those documents, we selected briefings, studies of planning, website development. As consequence of this study, we discovered that the creation process of the website did not occur in a linear manner; in fact, it allowed the use of mechanisms that provide the readability of the content to be transmitted by means of the composition of the visual message.
\end{abstract}

Key Words: Genetic criticism, creation process, web.

\section{Introdução}

$\mathrm{O}$ ato criador leva à construção de um objeto em uma determinada linguagem. Mas seu percurso é organicamente intersemiótico (SALLES, 2009, p. 118). Refletindo assim, todo o processo de criação, por si só, agrega um conjunto de fatores e filosofias impregnado de personalidade do criador ou do seu cliente. Este é um fato gerador de desentendimentos no processo de criação, pois muitas ideias e propostas, às vezes inviáveis, vêm à tona no momento de "nascimento" de um site, pois este, após conclusão, diferentemente de um escritório ou representação, fica disponível 24 horas por dia, sete dias por semana, ininterruptamente online, proporcionando o máximo de visibilidade de um produto.

\footnotetext{
${ }^{1}$ Mestrando em Comunicação, Linguagens e Cultura da Universidade da Amazônia (UNAMA), especialista em Comunicação Empresarial pela Faculdade da Amazônia (FAAM), bacharel em Comunicação Social: Habilitação em Multimídia e Relações Públicas pelo Instituto de Estudos Superiores da Amazônia (IESAM).

2 Doutoranda em Tecnologias da Inteligência e Design Digital pela Pontifícia Universidade Católica de São Paulo (PUC/SP), mestre em Comunicação e Semiótica pela Pontifícia Universidade Católica de São Paulo (PUC/SP), bacharel em Comunicação Social - Publicidade e Propaganda - pela Universidade da Amazônia (UNAMA), bacharel em Comunicação Social - Jornalismo - pelo Centro Universitário das Faculdades Integradas Alcântara Machado (FIAMFAAM), bacharel em Relações Públicas pelo Instituto de Estudos Superiores da Amazônia (IESAM).
} 
A utilização da web como ferramenta de desenvolvimento de um produto ou consolidação de uma marca ultrapassou o papel coadjuvante. O número crescente de acessos mostra o enorme potencial evidente de divulgação de produtos, por meio de sites bem elaborados e atraentes. No entanto, um site é o produto final de uma rede simbiótica de profissionais envolvidos no processo de criação, os quais analisam desde o produto até seu público-alvo, avaliando abordagens, criando o perfil, gerando vínculos entre empresa, produto e cliente. A análise do processo de criação de um site, seu mapeamento e a criação de uma postura ou código de conduta, são relevantes, pois dada a brevidade do surgimento de um novo meio de informação, criou-se uma rede sem padrões ordenados. No processo de criação para internet, acreditamos que ainda haja muito o que pesquisar e várias questões em aberto. Dentro desse universo, podemos levantar a seguinte questão: como se dá o processo de criação para a internet?

\section{Interatividade e interfaces gráficas}

Quando falamos em internet e todas essas possibilidades de acessar textos, ouvir músicas, assistir a vídeos, fazer downloads de arquivos, mandar e-mails, conversar com outras pessoas por meio de chats, logo pensamos na rede como a mais interativa das mídias. Mas o conceito de interatividade é antigo, parte do pressuposto de que toda obra tem seu potencial de interação; quando lemos um jornal, uma revista, ou um livro, estamos interagindo com os textos. A leitura é uma forma de interação, os textos estão enviando mensagens e estamos absorvendo, refletindo e, na maioria das vezes, mudando nossas vidas. Isso também acontece quando ouvimos música ou construímos algo novo.

\footnotetext{
Vivemos em um tempo em que nada acontece fora do universo tecnológico e a cada momento nos vemos diante da interação homem-máquina. A criação artística abre inúmeras possibilidades para essa confluência de conhecimentos que aproxima ciência, tecnologia e fazer artístico (DOMINGUES, 1997, p 34. ).
}

A internet tem a capacidade de reunir muitas formas de interação, é uma hipermídia que está em constante mutação. Os sites disponíveis na rede podem ser e, em sua maioria, são modificados a todo instante, tornando a internet bastante dinâmica. Podemos dizer que a hipermídia só se torna obra interativa em seu mais alto grau quando o usuário participa, manipulando-a, tornando-se coautor, construindo como um agente ativo um labirinto pessoal e único. 


\begin{abstract}
A hipermídia é um desenvolvimento do hipertexto, designando a narrativa com alto grau de interconexão, a informação vinculada [...]. Pense na hipermídia como uma coletânea de mensagens elásticas que podem ser esticadas ou encolhidas de acordo com as ações do leitor. As ideias podem ser abertas ou analisadas com múltiplos níveis de detalhamento (NEGROPONTE, 1995, p. 66).
\end{abstract}

Quando o usuário faz compras pela internet, ele transforma, manipula e solicita o produto que será baixado do estoque da loja e, ao mesmo tempo, informa a seu cartão de crédito ou conta bancária um novo débito que alterou uma estrutura de conteúdo. Quando o usuário faz pagamentos de contas por meio de um site de banco, ele está interagindo com sua conta corrente, ou quando envia uma mensagem para outra pessoa, ele está modificando a interface da caixa de mensagens do receptor. Dessa forma, ele, usuário, passa a fazer parte de um processo que está sempre em movimento.

A interatividade é caracterizada como "a arte da participação", é o receptor assumindo o papel de autor em uma obra aberta, uma obra em estado de possibilidade. Justamente no espaço virtual (ciberespaço), podemos visualizar, por meio da tela do computador, as marcas da ação do usuário ora receptor, ora destinatário.

\title{
Navegação
}

$\mathrm{Na}$ internet, encontramos uma infinidade de sites destinados aos mais variados públicos, oferecendo desde produtos e serviços até entretenimento e informação. Com a evolução rápida dessa mídia, muitos se preocupam em desenvolver seu site e colocá-lo no ar para não ficar de fora. A esse imediatismo, junta-se a falta de capacitação profissional. Muitos sites foram desenvolvidos, quanto ao conteúdo, de forma confusa ou genérica demais; em termos tecnológicos, com endereços e links confusos, contendo informações irrelevantes, que precisam de downloads lentos, em muitos casos.

Há vários sites que seguem a mesma estrutura independente de seus conteúdos. É importante pensar que o site precisa agregar valor ao usuário; pois hoje a maioria das pessoas não navega mais na rede, apenas visita alguns sites fixos, e faz uso de e-mail, chats e redes sociais. O profissional dessa área deve preocupar-se com o usuário, compreendendo suas necessidades.

Leão (1999), em Labirinto da Hipermídia, associa a arquitetura do ciberespaço com o do Oriente. Nesse sentido, a autora coloca a necessidade de construir um projeto bem organizado, e o espaço a ser concebido com algo mutável e flexível. Deve ser ressaltado que pensar a estrutura de navegação implica entender algumas questões tecnológicas, porém, neste 
estudo especificamente, abordamos a navegação por meio da interface gráfica, em seus aspectos estéticos e comunicacionais.

\title{
Processo de criação em web
}

No processo de criação de website, um elemento importante é a utilização da linguagem visual. Diariamente, os sinais incorporados aos conhecimentos humanos são de grande valia nesse processo, que exige rapidez e clareza no ato de transmitir informações ao usuário. Para auxiliar no processo de construção do projeto gráfico e da navegação, o web designerdeve possuir conhecimentos relacionados à comunicação visual. Neste aspecto, Munari (1997, p. 56) afirma:

\begin{abstract}
A comunicação visual é assim, em certos casos, um meio insubstituível de passar informações de um emissor a um receptor, mas as condições fundamentais do seu funcionamento são a exatidão das informações, a objetividade dos sinais, a codificação unitária e a ausência de falsas interpretações. Só será possível atingir essas condições se ambas as partes entre as quais ocorre a comunicação tiverem conhecimento instrumental do fenômeno.
\end{abstract}

No desenvolvimento da arquitetura da informação, uma das primeiras etapas após analisar os dados do briefing é pensar na página de abertura do site, a home page. Ela deve mostrar ao usuário como navegar pelo site e quais assuntos, produtos ou serviços o usuário irá encontrar. Desse modo, é importante que a home page destaque-se das demais páginas do site. Isso não significa um design totalmente diferente das outras páginas, apenas que algumas informações merecem um destaque maior, como a logomarca da empresa e os objetivos do site.

\section{Crítica genética e os novos meios}

Podemos definir crítica genética como a investigação que vê a obra de arte baseada em sua construção. Acompanhando seu planejamento, execução e desenvolvimento, o crítico genético preocupa-se com a melhor compreensão do processo de criação. Para a crítica genética, é importante "indagar de uma maneira mais ampla os modos como ocorre a produção de romances, filmes, programas de televisão, esculturas, vídeos e peças publicitárias" (SALLES, 2000, p. 24). O crítico genético é um pesquisador que comenta a história da produção de obras de natureza artística, seguindo as pegadas deixadas pelos criadores. Narrando a gênese da obra, ele pretende tornar o movimento legível e revelar algumas características responsáveis pela sua criação. Essa crítica procura reconstituir a 
gênese da obra com o material que possui e descrever os mecanismos que sustentam essa produção.

O foco de atenção da crítica genética é, portanto, o processo por meio do qual algo que não existia passa a existir, pautado em algumas características que alguém lhe oferece. Uma obra surge ao longo de um processo complexo de apropriações, transformações e ajustes. A crítica genética entra na complexidade do processo, mas a principal questão que impulsiona este estudo é a organização desse movimento. Não seria a interpretação da obra considerada final pelo criador, mas sim o processo responsável pela sua produção. Ressaltamos que só nos interessa estudar o processo de criação porque essa obra existe.

A crítica genética utiliza-se do percurso da criação para desmontá-lo e, em seguida, colocá-lo em ação novamente. Quando nos referimos a percurso, falamos sobre os rastros deixados pelo criador. $\mathrm{O}$ interesse dos estudos genéticos é o movimento criativo: o ir e vir do criador. Assim, o crítico passa a conviver com o ambiente do fazer, cuja natureza o criador sempre conheceu.

\section{Estrutura metodológica}

Este estudo tem como objetivo identificar e analisar os documentos que envolvem o processo de criação de páginas para internet, especificamente, o site do Instituto de Estudos Superiores da Amazônia (IESAM), vinculado em 2012; seu projeto gráfico e sua estratégia de navegação, dentro de todo o processo de comunicação desenvolvido na rede. É importante citar que abordamos a navegação do ponto de vista do projeto gráfico, que envolve questões estéticas e comunicativas. Porém, não entramos em questões tecnológicas. Assim, iniciamos o trabalho pelo levantamento dos documentos do processo de criação do site selecionado para estudo, entre esses documentos existem briefing (informações do instituto, produtos e serviços, consumidores, mercado), esboços de planejamentos, desenvolvimento de sites, arquivos digitais, entre outros.

No campo da comunicação identificamos e analisamos os documentos que envolvem o processo de criação de um website. Estudamos o percurso que vai do levantamento das informações - briefing ao planejamento - o roteiro de navegação, estrutura, execução e desenvolvimento do website.

Dentro da expansão dos limites dos estudos genéticos, buscamos com esta pesquisa desenvolver o estudo dos documentos do processo de criação para internet, mais precisamente, no processo criativo de um website. 


\section{Análise do processo criativo em web: caso IESAM}

Os websites institucionais estão ligados aos serviços por eles prestados, que neste caso é o campo educacional de ensino superior. E é de suma importância ressaltarmos que, além dos conteúdos informacionais e da própria arquitetura, os websites institucionais estão cada vez mais ligados à tecnologia e suas possibilidades de inovação fazendo com que se qualifiquem cada vez mais.

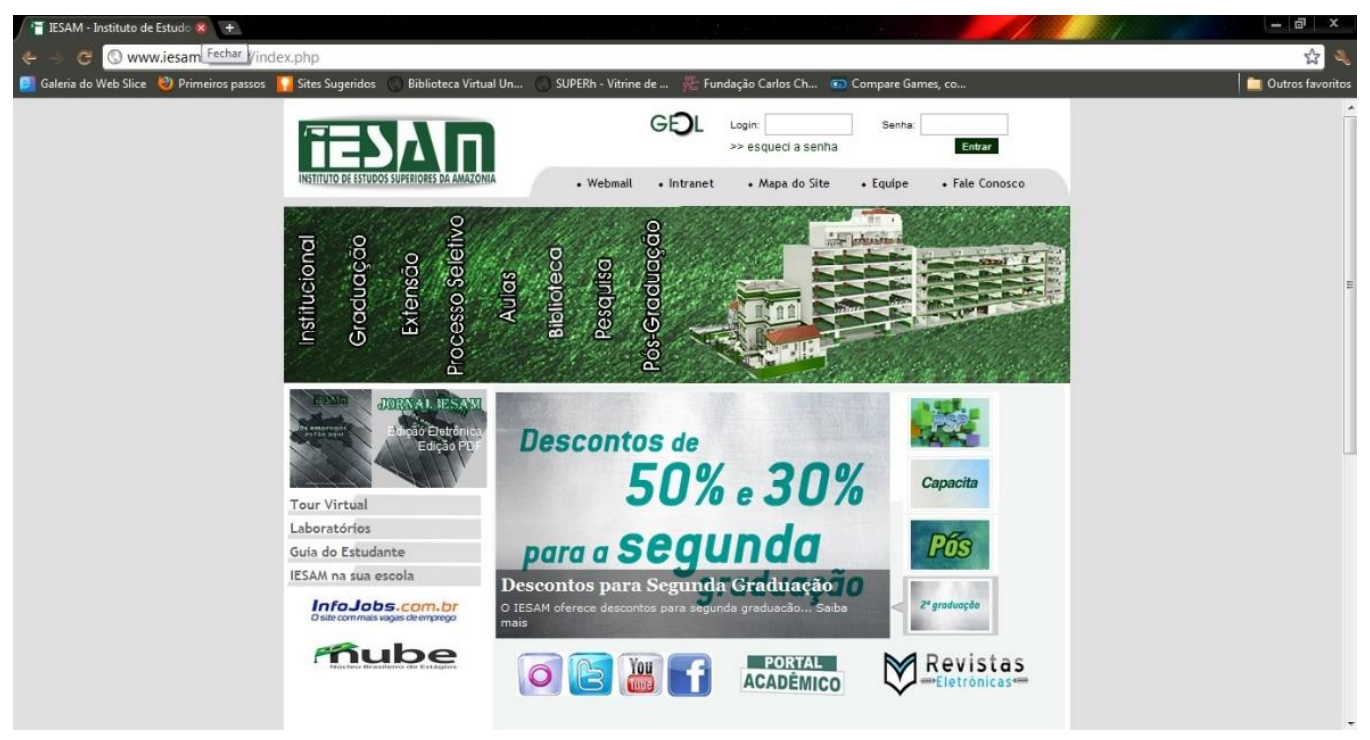

Figura 01: Home Page inicial do IESAM

Fone: www.iesam.edu.br (2012)

Um portal, em sua exigência, deve mostrar uma interface amigável, obedecendo fielmente a quem frequenta seu domínio e as possibilidades de serviços oferecidas ao usuário. Exemplo desta possibilidade de serviço, dentro do site do IESAM, é o Geol, que permite ao aluno ter acesso ao boletim financeiro, solicitação de documentação, dentro outros aspectos que vêm atender ao usuário, conforme a figura 02 .

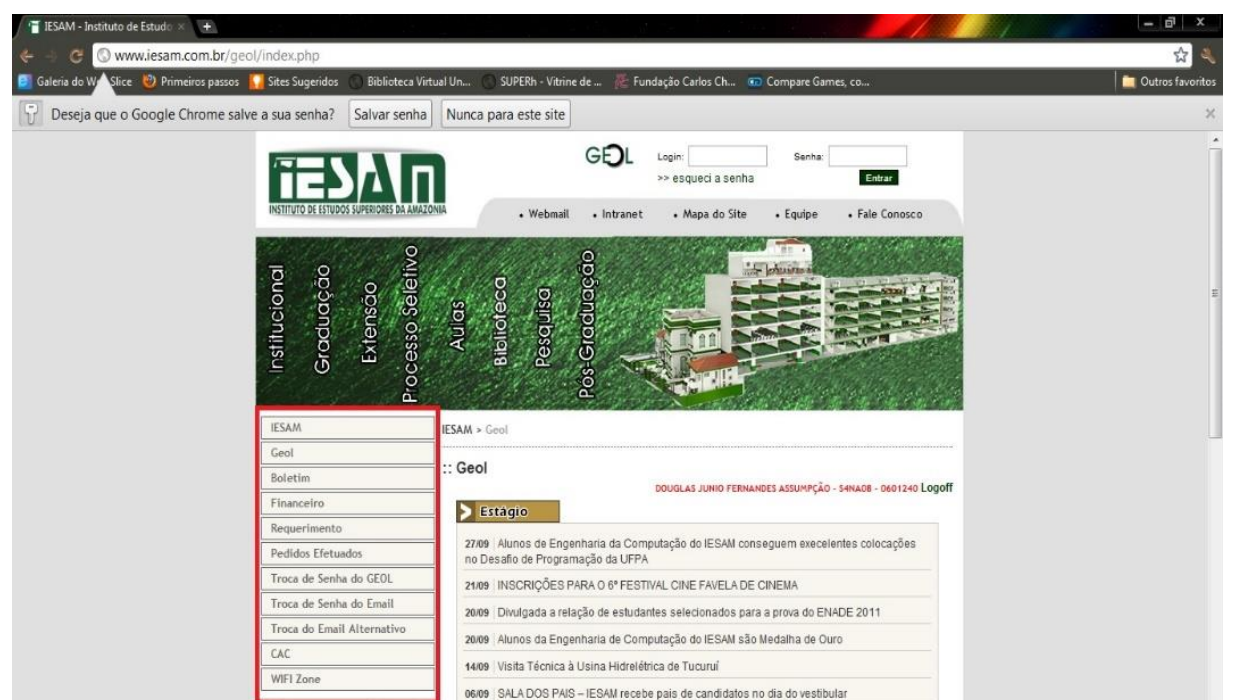


Figura 02: Página restrita ao aluno/sistema Geol.

Fone: www.iesam.edu.br (2012)

Assim como o sistema de serviço ao aluno, Geol, o IESAM fornece a seu público interno um e-mail institucional. Portanto, ressalto neste ponto o que Damasceno (2011 p. 61) diz: “[...] todos os recursos são válidos e dependem basicamente do layout e dos outros itens da página, mas é importante deixar a busca à primeira vista do usuário, sem que eles necessitem utilizar a rolagem de tela para encontrar", conforme mostra a figura 03.

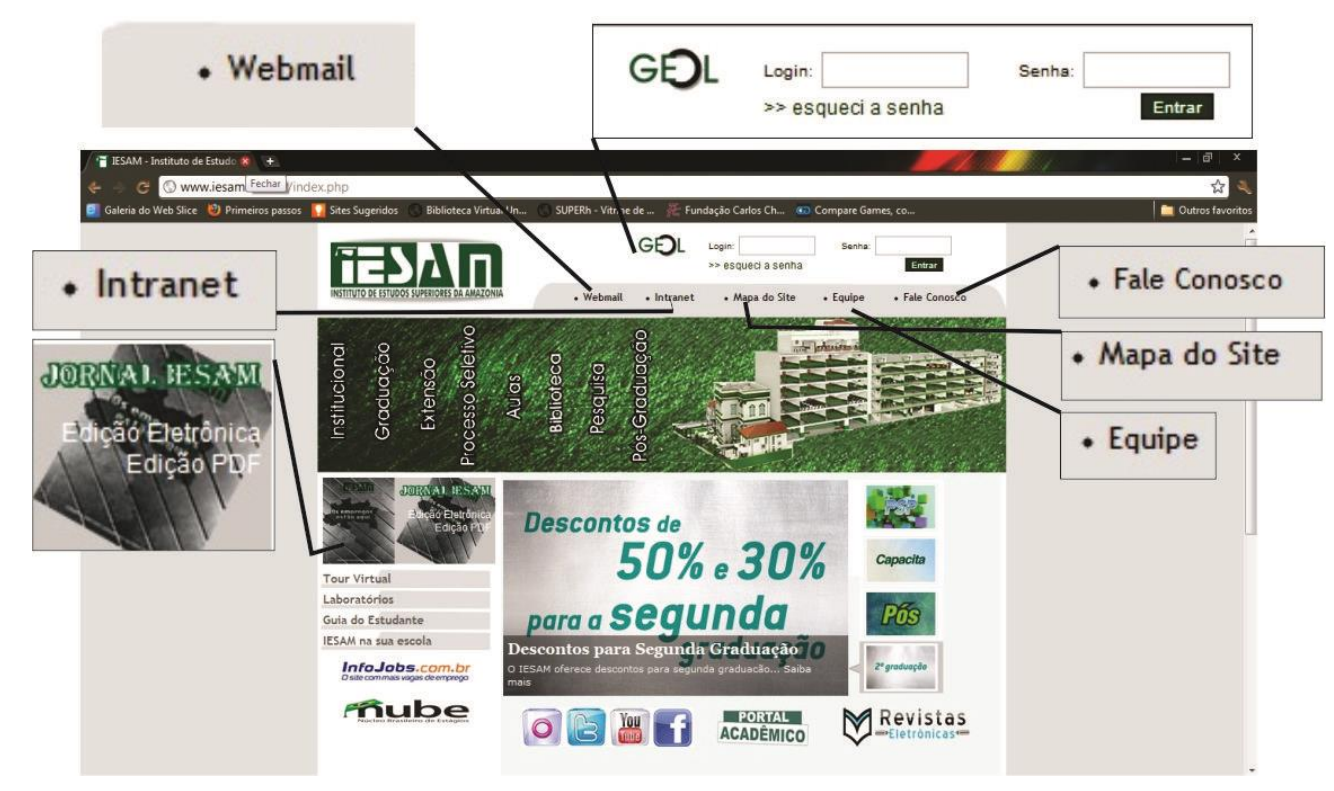

Figura 03: Página do IESAM, com destaques nos recursos da página.

Fonte: www.iesam.edu.br (2012)

Outro recurso encontrado na página é a barra em flash, que complementa sua construção nos recursos de informação e interação com o usuário, caracterizando-se como um menu de navegação, que, segundo Damasceno (2011. p. 83), surgirá para organizar a navegação e as seções internas de site de modo a serem encontradas facilmente pelos visitantes. É notável que um menu de navegação é de suma importância para a constituição do site, pois é nele que estarão centrados todos os componentes informacionais acerca da organização.

Nota-se que no website do IESAM há uma preocupação com a usabilidade que aqui temos, por ser sinônimo de facilidade de uso. Um produto fácil de usar gera mais 
produtividade, alcançando um bom desempenho, adequando-se aos seus usuários e possibilitando uma fácil utilização dos recursos. Mas este conceito não é tão novo como parece, possui cerca de 50 anos e pode também ser chamado por "amigável", ou desenvolvimento de produto orientado para o consumidor (ZILSE, 2003).

Esse termo só se tornou popular com a internet e, provavelmente, isso ocorreu devido à interatividade que começou a ser uma necessidade dos websites em serem mais atraentes aos usuários. O objetivo da usabilidade nesse projeto é demonstrar alguns dos métodos que podem ser utilizados na construção de interface. Usabilidade é o termo técnico usado para descrever a qualidade de uso de uma interface (BEVAN, 1995).

\section{Mecanismos do processo}

Ao analisarmos os documentos digitais, index.html, percebemos que o web designerpartiu de um layout básico da estrutura de navegação, e cada passo do processo foi aprimorando seu projeto no nível da navegação e da interface gráfica, incluindo elementos, conteúdos e links que, muitas vezes, auxiliam no deslocamento do internauta dentro do website. O web designerprecisa fazer mudanças ao longo do percurso do processo de criação, são escolhas que vêm ao encontro de objetivos traçados pelo cliente, o instituto IESAM, e pelas necessidades do público-alvo. De forma clara, vemos as transformações dos layouts por intermédio dos mecanismos de adição, corte, substituição e deslocamento de elementos promovidos pelo webdesigner, a respeito desses mecanismos trataremos a seguir.

\section{Adição}

O mecanismo de adição é o mais constante no processo, ele está presente em maior número em relação aos outros mecanismos. A cada layout, o web designer procura inserir elementos que completem as informações ali contidas.

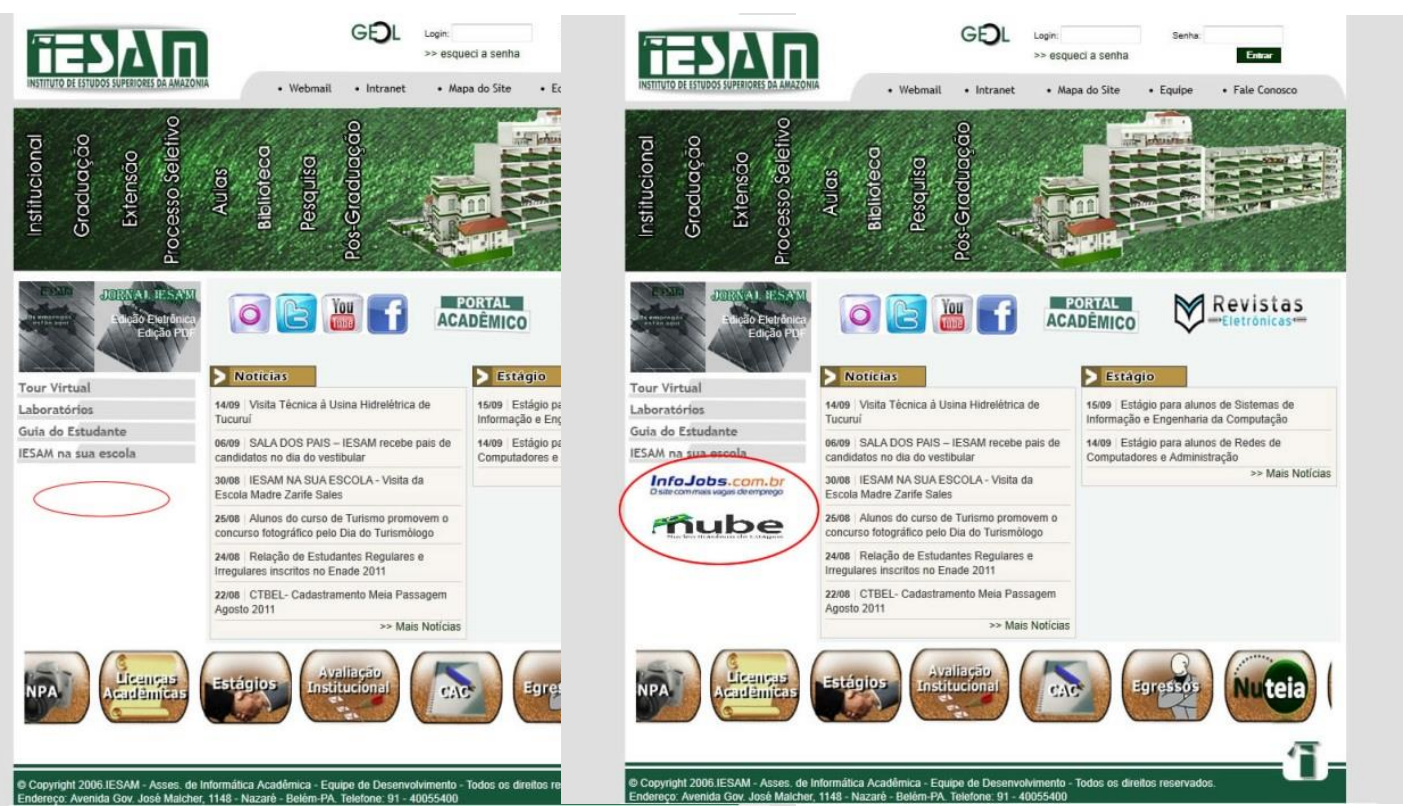


Figura 04: Exemplo de adição dentro da página do IESAM

Fonte: Assessoria de Informática do IESAM (2012)

Vimos aqui alguns elementos que foram sendo adicionados ao longo do processo de criação. Este com certeza é o maior mecanismo que o web designer utiliza ao longo do processo, a Adição.

A cada novo layout, o web designer vai acrescentando elementos e informações que se fizeram necessários ao projeto, seja por meio de dados do briefing, seja em nome de uma interface gráfica mais clara, tornando a navegação mais fácil ao internauta, assim como é percebido na figura 5:

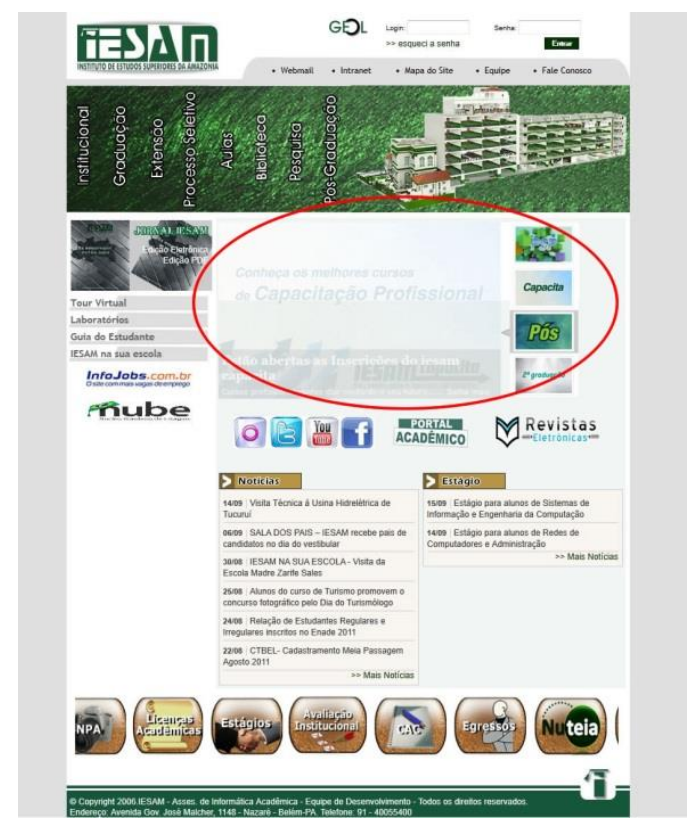

Figura 05: Exemplo de adição dentro da página do IESAM

Fonte: Assessoria de Informática do IESAM (2012) 


\section{Corte}

O segundo mecanismo que o web designer utiliza é o corte, em uma proporção menor ao mecanismo da adição. Ao longo do processo de criação, o web designer vai identificando elementos que se tornam dispensáveis ao projeto, seja pela falta de conteúdo ou por não auxiliarem de forma alguma na navegação.

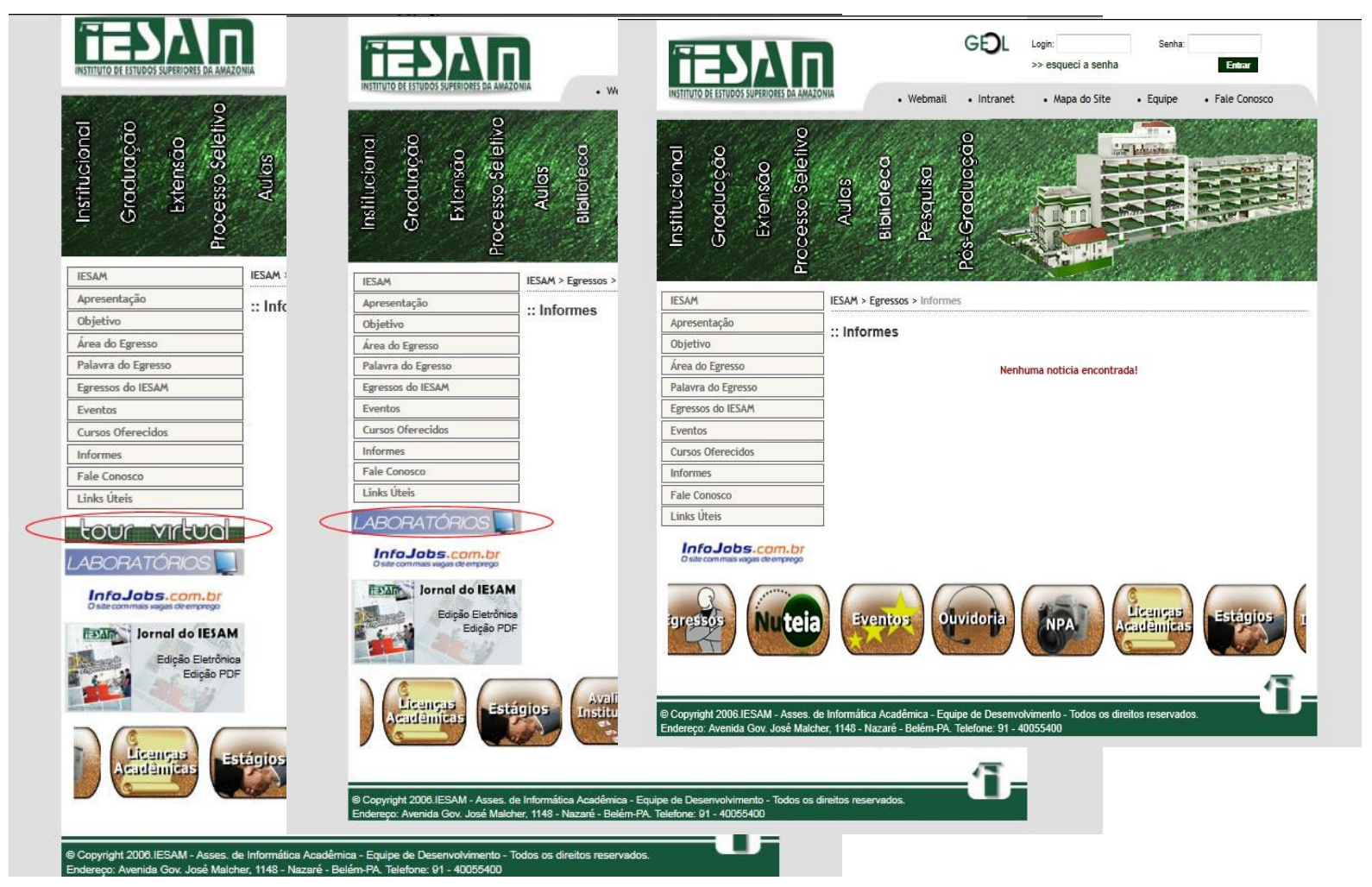

Figura 06: Exemplo de corte dentro da página do IESAM

Fonte: Assessoria de Informática do IESAM (2012)

O corte faz-se necessário conforme o web designer percebe quais conteúdos estão sendo repetidos, ou que não existe um conteúdo suficiente para mantê-los, e que tais informações podem tornar o site confuso do ponto de vista do usuário. 


\section{Substituição}

Nos documentos do processo de criação, encontramos outro mecanismo utilizado pelo web designer, a substituição. Percebemos que tal mecanismo apresentou-se pouquíssimas vezes durante o percurso.

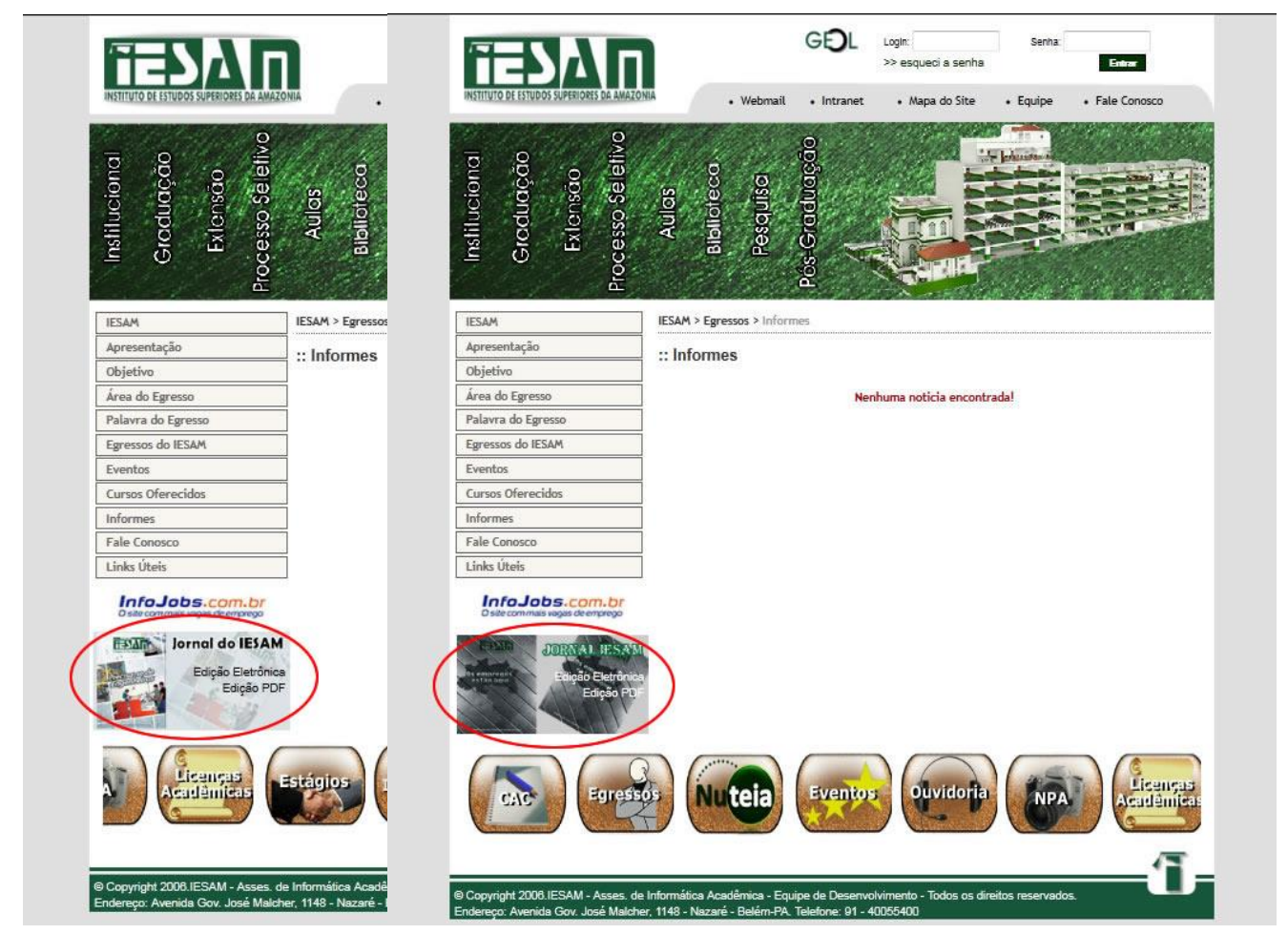

Figura 07: Exemplo de substituição dentro da página do IESAM

Fonte: Assessoria de Informática do IESAM (2012)

O mecanismo de substituição foi pouco utilizado pelo web designer, mas a adequação dos elementos e palavras em uma linguagem digital aproxima o internauta, deixando-o mais à vontade; sob esse aspecto a substituição torna-se um mecanismo fundamental no processo criativo. 


\section{Deslocamento}

O deslocamento dos elementos nas páginas é outro mecanismo que o web designer trabalha no processo de criação.

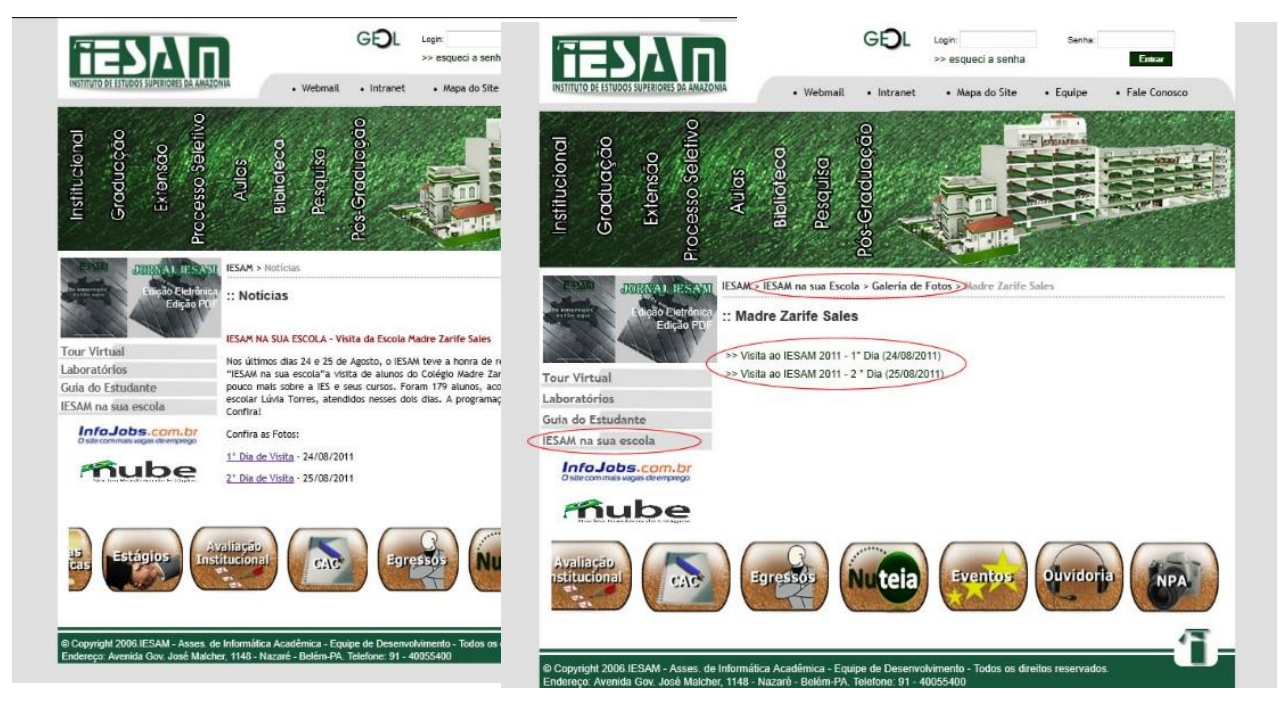

Figura 08: Exemplo de Deslocamento dentro da página do IESAM

Fonte: Assessoria de Informática do IESAM (2012)

O web designer utiliza o mecanismo de deslocamento de elementos e conteúdo para atrair a atenção do internauta, procurando deixá-lo informado sobre o que ocorre no mercado e no próprio site.

É importante citar que os mecanismos de Adição, Corte, Substituição e Deslocamento não ocorrem apenas nesse tipo de processo de criação. Tais mecanismos podem ser percebidos em outros processos de criação, como na literatura, nas artes plásticas, publicidade, entre outros. Durante o processo de criação, o criador precisa fazer escolhas, optando por elementos ou linguagens mais eficientes, inserir conteúdos adequados às necessidades de seu público e excluir informações que se tornem desnecessárias ao longo do projeto. Além de manipular os dados, mudando-os de posição e tornando-os mais adequados aos objetivos.

Notamos que os mecanismos identificados nesse processo criativo estão relacionados ao desenvolvimento de uma interface gráfica amigável e à usabilidade do site. Assim, um dos 
aspectos mais importantes, nesse tipo de processo criativo, é o emprego do design, trabalhando a ergonomia e usabilidade de forma adequada em interfaces gráficas.

O web designer, neste caso, projetou o website do IESAM de forma que o usuário pudesse navegar sem dificuldades. Quando o homem incorporou ao seu dia a dia o uso da internet, ele aprendeu a lidar com esse novo meio, a movimentar-se na rede através de links, ícones e índices. Ao visualizar a tela, ele identifica os menus e sabe que, ao clicar sobre eles, será levado a algum tipo de informação. Podemos dizer que a interface gráfica desenvolvida para o website do IESAM é simples e não requer do usuário conhecimentos mais específicos ou tecnológicos para a navegação.

Em todos os processos criativos, notamos os movimentos de ir e vir de seus criadores. A utilização dos mecanismos anteriormente citados é constante em processos de criação, mas é importante lembrar que, neste caso, a adição foi o mecanismo mais acentuado, pois o projeto iniciou-se com uma estrutura básica, e ao longo do processo foi sendo adicionada uma grande quantidade de elementos e informações, que foram completando e formando o website. Como podemos ver nos diagramas a seguir.

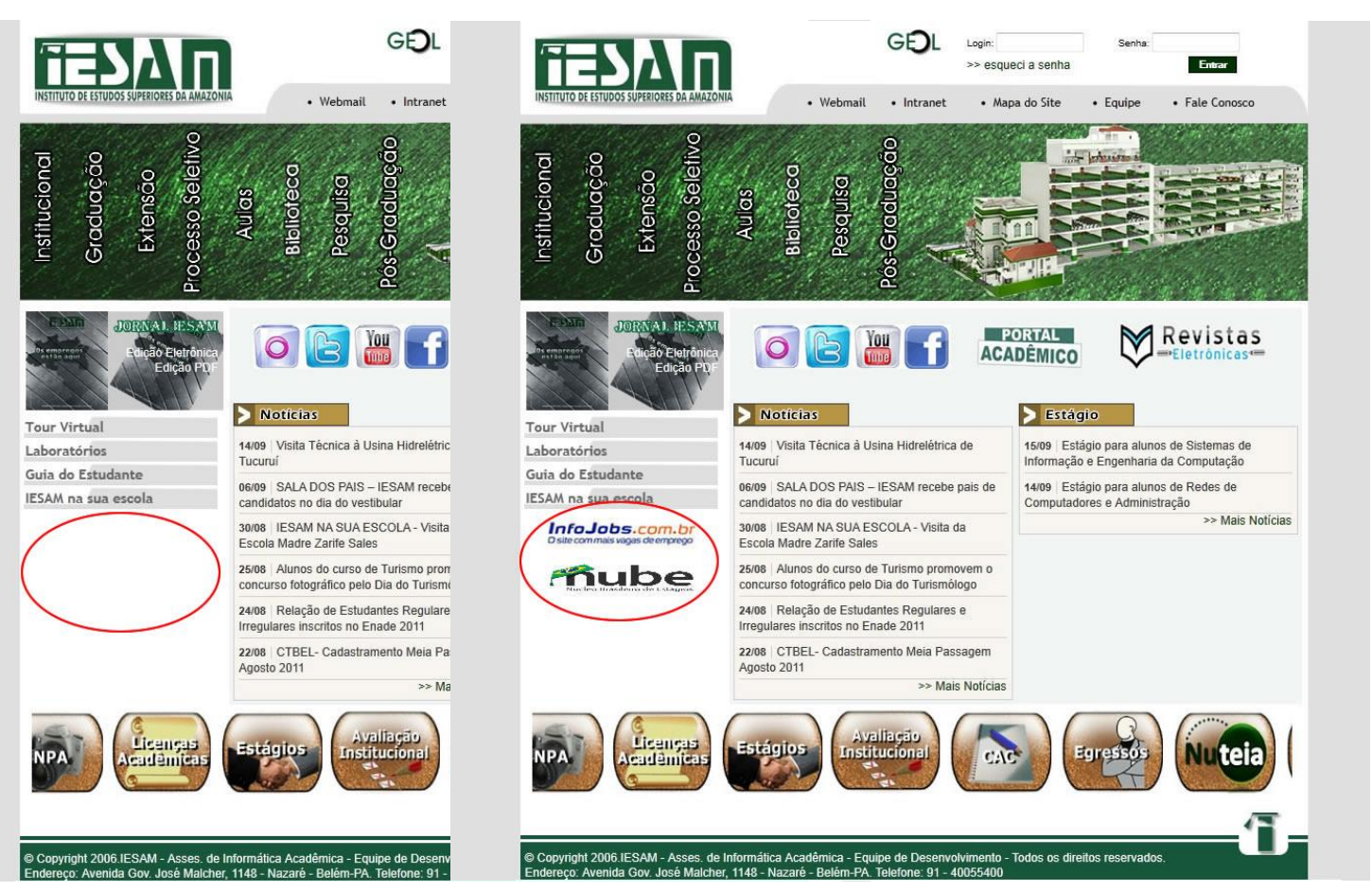

Figura 09: Exemplo de elementos adicionados no site - exemplo 01

Fonte: Assessoria de Informática do IESAM (2012) 

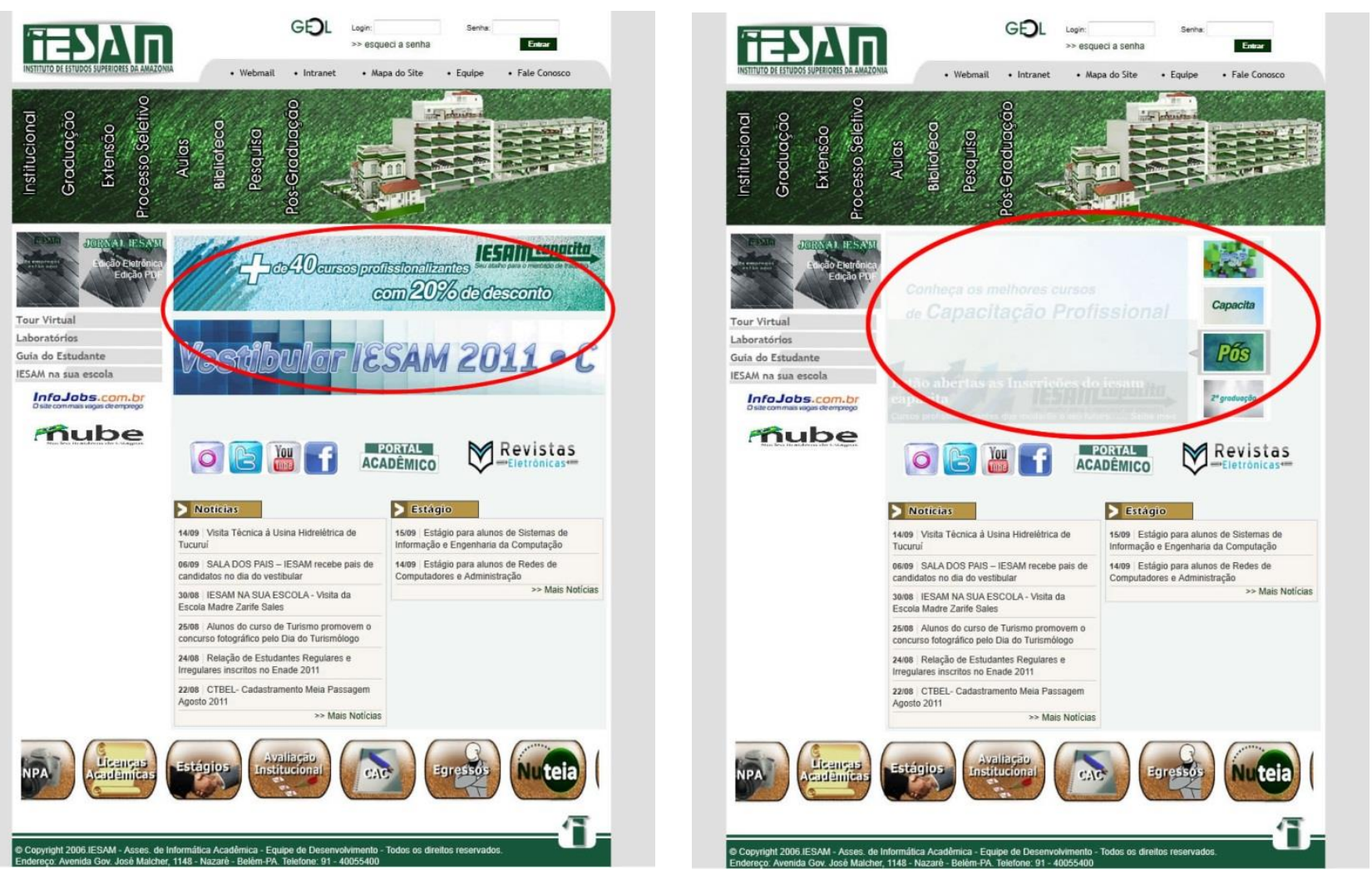

Figura 10: Exemplo de elementos adicionados no site - exemplo 02 Fonte: Assessoria de Informática do IESAM (2012)

O mecanismo de adição é típico desse processo criativo, sobretudo quando falamos em novos meios, no dinamismo da rede, no mundo globalizado, com novas necessidades surgindo a cada instante. Como ainda há muito a aprender com essas novas tecnologias, a quantidade e, especialmente, a qualidade das informações e elementos são fundamentais para auxiliar na navegação do internauta e simplificar o processo comunicacional.

\section{Considerações finais}

A internet é uma grande aliada das empresas para a realização de negócios, seja para novos negócios ou complementação de outros já existentes no mercado. Como uma ferramenta de apoio ao marketing, tornou-se um canal de aproximação com seus clientes, seu público-alvo em potencial. A rede é construída de forma livre, não existe um controle de 
qualidade, nem no que diz respeito à interface gráfica, nem a conteúdo. Qualquer pessoa pode desenvolver um site e colocá-lo no ar, apenas utilizando softwares apropriados; não há necessidade de concessões governamentais, como no caso da TV. A única exigência é que se faça um registro do endereço do site, para que não haja problemas de conflitos nas buscas e nas navegações por nomenclaturas repetidas. Esse registro e sua manutenção são feitos a um custo quase que irrelevante.

As escolhas e decisões pelos elementos que farão parte da composição visual constituem o processo criativo e, nesse caso, como todo e qualquer processo comunicacional, que tem como objetivo a compreensão por parte do receptor, essas escolhas precisam ser feitas com bastante cuidado. Podemos ver que o processo criativo de um website assemelha-se a outros processos criativos que têm como objetivo fins comerciais, divulgação de produtos e serviços em comunicação. Como no caso do processo criativo da propaganda, que, ao longo do percurso, os publicitários que trabalham diretamente com criação de mensagens precisam fazer escolhas de imagens e textos que sejam mais adequados a essas mensagens produzidas com a finalidade de persuadir o consumidor e gerar o desejo de aquisição do produto. Os profissionais o executam também pautados em informações de briefing (perfil de mercado, público-alvo, concorrentes etc.) e em objetivos traçados pelo cliente, em relação ao mercado e à comunicação. Conforme observamos no trecho descrito por Bertomeu (2002, p. 39): “O briefing parece ser um instrumento que o profissional de criação utiliza para balizar o processo, mas não é ferramenta definitiva para o bom resultado criativo de uma propaganda".

Neste estudo de caso, encontramos alguns pontos em comum entre os processos criativos para internet e para a propaganda, ambos por meio de objetivos comerciais, procuram caminhos que conduzam a tais objetivos que, em especial, os elementos escolhidos auxiliem de forma efetiva no processo comunicacional.

O processo criativo do web site do instituto IESAM não ocorreu de forma linear. Iniciou-se linearmente por meio dos dados do briefing, mas durante seu percurso o movimento de ir e vir tornou-se constante. Ao mesmo tempo que o web designer adicionou conteúdos, imagens, fez recortes, substituições e deslocamentos, ele foi percebendo informações repetidas ou confusas e foi adaptando-se às necessidades e objetivos do instituto.

O internauta acaba por definir uma série de procedimentos que serão adotados pelo web designer na construção do site, com a forma de aprendizagem dos movimentos e a quantidade de clicks que ele deverá fazer para que possa navegar no website. Os sistemas de ícones são elementos que tornam a interface gráfica mais simples e com um menor número de 
distrações, uma arquitetura de informação clara e ferramentas de navegação correspondentes. Essas ações tornam o site mais funcional, auxiliando no processo comunicacional. Percebemos que isso foi buscado ao longo do processo.

O web designer deve fazer uso de mecanismos que proporcionem a legibilidade dos conteúdos a serem transmitidos por meio da composição da mensagem visual. A interface gráfica está intimamente ligada ao desenvolvimento da navegação e irá direcionar o internauta. Desse modo, os profissionais da área digital, além de conhecerem os dados diretamente relacionados a seus clientes, como produtos, serviços, mercados em que atuam, concorrência e público-alvo. Devem ter domínio de conhecimentos sobre design gráfico, aplicando-os de forma adequada, fazendo com este auxilie no processo comunicacional associado à estética, para que possam obter sucesso em seus projetos de website.

(Artigo recebido em 07/07/2013, aceito em 27/08/2013)

\section{Referências}

BAIRON, S. Multimídia. São Paulo: Global, 1995.

BERTOMEU. J. V. C. Criação na Propaganda Impressa. São Paulo: Futura, 2002.

BEVAN, N. Usability is quality of use. In: Anzai \& Ogawa (eds) Proc. $6^{\text {th }}$ International Conference on Human Computer Interaction, July (1995). Elsevier. Disponivel em: <citeseerx.ist.psu.edu/.../download?doi=10> Acesso em: 29 set. 2011.

DOMINGUES, Diana (Org.). Arte no Século XXI: a humanização das tecnologias. São Paulo: Editora UNESP, 1997.

LEÃO, L. O Labirinto da Hipermídia - arquitetura e navegação no ciberespaço. São Paulo: Iluminuras, 1999.

MUNARI. B. Design e Comunicação Visual. São Paulo: Martins Fontes, 1997.

NEGROPONTE, Nicholas. A Vida Digital. São Paulo: Companhia das Letras, 1995.

SALLES, C.A. Crítica Genética: uma (nova) introdução. 2. Ed. São Paulo: Educ, 2000.

Crítica Genética: fundamentos dos estudos genéticos sobre o processo de criação.

3. ed. São Paulo: Educ, 2008.

ZILE. Renata. Usabilidade não nasceu ontem e tem história. Disponível em: <http://webinsider.uol.com.br/2003/01/10/usabilidade-nao-nasceu-ontem-e-tem-historia/>. Acesso em: 29 set. 2011. 